\title{
Self-healing Capacity of Fiber Reinforced Cementitious Composites. State of the Art and Perspectives
}

\author{
E. Cuenca* and L. Ferrara**
}

Received May 9, 2016/Revised September 29, 2016/Accepted January 1, 2017/Published Online February 17, 2017

\begin{abstract}
Design of building structures and infrastructures is mainly based on four concepts: safety, serviceability, durability and sustainability. The latter is becoming increasingly relevant in the field of civil engineering. Reinforced concrete structures are subjected to damages that produce cracks which, if not repaired, can lead to a rapid deterioration and would result into increasing maintenance costs to guarantee the anticipated level of performance. Therefore, self-healing concrete can be very useful in any type of structures, as it allows to control and repairing cracks as soon as they are likely to occur. The effectiveness of self-healing can be improved with the use of fibers due to their capacity to control crack width and enhance multiple crack formation. In that way, researchers should use advanced cement based materials (FRCC, HPFRCC, etc.) and techniques (autogenous and engineering healing) to satisfy all demands in which sustainability and durability are key factors. Compared to the large number of investigations on selfhealing of plain concrete, self-healing studies on Fiber Reinforced Cementitious Composites (FRCC) are still limited. Therefore, the main objective of this paper is to provide a deep literature review on this subject in order to clarify what is known (What now?) and finally to identify those gaps which still require further studies (What next?) such as: healing capacity under sustained stress, repeatability healing/cracking cycles as well as healing capacity for cracks and damages occurring at later concrete ages.
\end{abstract}

Keywords: self-healing, concrete, fiber, durability, mechanical behavior

\section{Introduction}

Sustainability in the field of civil engineering is becoming increasingly relevant and, in the field of construction, this concept is closely related with durability. Building performances should be maintained over time in order to avoid interventions of repair or demolition, which represent a problem to the society, both in economic terms and environmental impact.

The use of materials with the ability to repair themselves (selfhealing materials) without outside intervention reduces the need for repair, which leads to extend the building and structure service life. Moreover, even though the initial costs are generally higher, these materials are an interesting option in the world of engineering construction since the future life cycle cost very strongly benefit from their use. But, what mechanisms make possible that concrete repairs itself?

In most of the conventional concrete mix-compositions, about $20-30 \%$ of the cement remains anhydrous. The amount of nonreactive material increases with decreasing the water/cement ratio. The particles can hydrate through direct contact with water or water vapor. When a crack or a damage occurs, the anhydrous cement particles inside a structural element can come into contact with water, in any form, and hydration could be activated resulting "delayed hydration products" can contribute to the closure of the crack. This mechanism is known since 1836 (Hearn and Morley, 1997) and is called autogenous healing (selfrepair) of concrete.

The calcium hydroxide is a product of the hydration of cement which, in the presence of water, forms precipitates on the surface of the crack. From this chemical reaction, calcium ions are obtained. These ions react with carbon ions obtained from carbon dioxide contained in the atmosphere or dissolved in water. This reaction forms calcium carbonate.

As long as there is the presence of calcium hydroxide, water and carbon dioxide, a continuous precipitation of calcium carbonate on the surface of the damage take place. The formation of these "carbonation" products can lead to the complete reclosure of the crack over time.

Compared with the large number of investigations on selfhealing of plain concretes (Ohama, Demura and Endo, 1992), (Edvarsen, 1999), (Reinhardt and Jooss, 2003), (Yang et al., 2009), (De Rooij et al., 2013), studies on FRCC are more limited (Mihashi and Nishiwaski, 2012), (Li, 2012), (Snoeck and De Belie, 2015a). Therefore, the main objective of this paper is to

\footnotetext{
*Postdoctoral Fellow, Dept. of Civil and Environmental Engineering, Politecnico di Milano, Piazza Leonardo da Vinci 32, 20133 Milan, Italy (Corresponding Author, E-mail: estefania.cuenca@polimi.it)

**Associate Professor, Dept. of Civil and Environmental Engineering, Politecnico di Milano, Piazza Leonardo da Vinci 32, 20133 Milan, Italy (E-mail: liberato.ferrara@polimi.it)
} 
summarize the research performed so far on the topic highlighting the achieved milestones and identifying the most important research needs in order to promote an effective and broad and consistent development of self-healing fiber reinforced cementitious composites.

In order to effectively pursue the aforementioned goal, in this paper distinction will be made between ordinary Fiber Reinforced Concrete (FRC) and High Performance Fiber Reinforced Concrete (HPFRC) and cementitious composites (HPFRCCs), sealing or healing of the cracks as well as between autogenous and engineered healing according to the definition by RILEM TC 221 (Schlangen and De Rooij, 2013a) and RILEM SHE (Xing and Schlangen, 2016).

Due to the technological, social and economic developments, the requirements for design and construction of structures has evolved as well (Li, 1992a), (Li and Leung, 1992b). For that reason, researchers have to design new materials (FRCC and HPFRCCs) and techniques (autogenous and engineered healing) to satisfy all those demands in which sustainability and durability are key factors.

The most important concepts on self-healing in fiber reinforced concretes and cementitious composites will be described hereafter to make up the framework of this paper.

Fiber Reinforced Concretes (FRCs) can be classified mainly in two types: ordinary FRC (employing low and moderate fiber volume fractions) and High-Performance Fiber Reinforced Concrete (HPFRC). In the former type of composite, fibers can be used to control shrinkage cracking (if employed in low volume percentages: e.g. $0.2-0.3 \%$ ) as well as partial/complete replacement of some kind of conventional reinforcement (stirrups, welded wire meshes, etc.). In this case, fiber volume percentages ranges between 0.5 and $1 \%$. With these fiber volume percentages, the composites still feature a strain-softening behavior, even if retaining a certain post-cracking tensile load bearing capacity, depending on fiber types dosage, dispersion and fiber/matrix bond.

With high fiber volume percentages (between $1 \%$ and $2 \%$ ) higher improvements in mechanical performance can be obtained, e.g. achieving a tensile strain-hardening behavior with stable multiple crack formation before the onset of unstable singlecrack localization.

This behavior can be obtained by optimizing -though tailored mix composition- the microstructure of the composites and the fiber/matrix interaction.

Multiple cracking results in high deformation capacity, which, keeping the width of the single crack below $100 \mu \mathrm{m}$ or even lower, implies improved ductility (Sahmaran and Li, 2008), higher damage tolerance (Fukuyama and Suwada, 2003), as well as enhanced energy dissipation capacity (Fisher and Li, 2002).

Regarding to sealing and healing of the cracks, this paper will differentiate them according to the definitions by RILEM TC 221. In fact, to verify crack sealing the recovery against environmental action will be analyzed and to verify crack healing the recovery against mechanical action will be measured.

With reference to crack self-sealing/healing, it can be classified into two categories: autogenous and engineered healing (De
Rooij et al., 2013). Autogenous healing was already observed by the French Academy of Science in 1836 (Snoeck and De Belie, 2015a). Autogenous healing is the self-healing process in which cracks are healed with materials formed by the cementitious matrix and therefore, materials that are not intentionally added in the matrix and not specifically designed for self-healing. This healing products are mainly produced by hydration of unhydrated cement particles and subsequent carbonation of calcium hydroxide (Van Tittelboom et al., 2012). On the other hand, the recovery process is called engineered healing when engineering additions specifically designed for self-healing are added in the matrix (Van Tittelboom et al., 2013a).

Synergy between fiber reinforced concrete cementitious composites and self-healing techniques may result into promising solutions. Fibers improve self-healing process due to their capacity to restrict crack widths and enhance multiple crack formation (Van Tittelboom, et al., 2012), (Wu et al., 2012), (Mihashi and Nishiwaski, 2012), (Qian et al., 2010), (Nishiwaki et al., 2012; 2014), (Yang et al., 2011a), (Cuenca et al., 2010; 2013a; 2013b; 2015a; 2015b). In particular, cracks smaller than $30 \mu \mathrm{m}$ healed completely (Snoeck et al., 2014) or even $50 \mu \mathrm{m}$ (Li et al., 1997), (Yang et al., 2009).

Moreover, in the case of HPFRCCs, high content of cementitious/ pozzolanic materials and low water binder ratios are likely to make the composites naturally conducive to self-healing (Özbay, et al., 2013).

In this framework the main goal of this paper is twofold.

On the one hand a state-of-the-art survey on self-healing of fiber reinforced concrete and cementitious composites will be provided in order to clarifying what it is known. On the other hand, the same state-of-the-art will be instrumental at identifying research needs which still have to be addressed to carry out a proper use of self-healing fiber reinforced cementitious composites in the construction field.

\section{Self-healing Capability of Fiber Reinforced Cementitious Composites. What Now?}

In this section, the state-of-the-art will be presented about the self-healing capacity of Fiber Reinforced Cementitious Composites, including ordinary FRCC and high-performance FRCC (HPFRCC). According to the literature survey on self-healing, concrete has been reinforced with fibers made of different materials (Table 1). The frequency of use of fiber materials is clearly shown in Fig. 1, where it can be observed that the most used materials for fibers is Polyvinyl Alcohol (PVA) (41\% are referred to surveyed studies) followed by steel, polypropylene and natural fibers with a $12 \%$. The other materials resulted in a minor number of cases.

\subsection{Self-healing of Ordinary FRCC}

\subsubsection{Autogenous Healing of Ordinary FRCC}

Several authors have investigated autogenous healing of ordinary FRCCs; the most important investigations are referred 
Table 1. Fiber Materials Used in the Self-healing Investigations

\begin{tabular}{|c|c|}
\hline Material & References \\
\hline Glass & $\begin{array}{l}\text { (Snoeck and De Belie, 2015a) } \\
\text { (Li et al., 1998) }\end{array}$ \\
\hline Steel & $\begin{array}{l}\text { (Snoeck and De Belie, 2015a) } \\
\text { (Ferrara et al., 2015a) } \\
\text { (Garas et al., 2009) } \\
\text { (Rossi et al., 2014) } \\
\text { (Kim et al., 2014) }\end{array}$ \\
\hline Natural & $\begin{array}{l}\text { (Snoeck and De Belie, 2015a) } \\
\text { (Van Tittelboom and De Belie, 2013b) } \\
\text { (Ferrara et al., 2015a) } \\
\text { (Snoeck and De Belie, 2012) } \\
\text { (Snoeck et al., 2015b) }\end{array}$ \\
\hline $\begin{array}{l}\text { Polyvinyl alcohol } \\
\text { (PVA) }\end{array}$ & $\begin{array}{l}\text { (Van Tittelboom and De Belie, 2013b) } \\
\text { (Li and Li, 2011) } \\
\text { (Kan } \text { et al., 2010) } \\
\text { (Snoeck et al., 2014) } \\
\text { (Nishiwaki } \text { et al., 2012) } \\
\text { (Sahmaran } \text { et al., 2015) } \\
\text { (Snoeck et al., 2016) } \\
\text { (Snoeck and De Belie, 2012) } \\
\text { (Nishiwaki } \text { et al., 2015) } \\
\text { (Nishiwaki } \text { et al., 2014) } \\
\text { (Özbay et al., 2013) } \\
\text { (Sahmaran and Li, 2008) } \\
\text { (Kim and Schlangen, 2011) } \\
\text { (Yang et al., 2009) } \\
\text { (Yildirim et al., 2015a) } \\
\text { (Sahmaran } \text { et al., 2015) } \\
\text { (Qian S. et al., 2009) }\end{array}$ \\
\hline Polypropilene (PP) & $\begin{array}{l}\text { (Sanjuán et al., 1997) } \\
\text { (Nishiwaki et al., 2012) } \\
\text { (Nishiwaki et al., 2014) } \\
\text { (Homma et al., 2009) } \\
\text { (Li et al., 1998) }\end{array}$ \\
\hline Polyacetal & (Nishiwaki et al., 2012) \\
\hline $\begin{array}{l}\text { Ethylene vinyl alcohol } \\
\text { copolymer (EVOH) }\end{array}$ & $\begin{array}{l}\text { (Nishiwaki et al., 2012) } \\
\text { (Nishiwaki et al., 2014) }\end{array}$ \\
\hline Polyethylene (PE) & $\begin{array}{l}\text { (Snoeck and De Belie, 2015a) } \\
\text { (Nishiwaki et al., 2014) } \\
\text { (Homma et al., 2009) }\end{array}$ \\
\hline Alumina $\left(\mathrm{Al}_{2} \mathrm{O}_{3}\right)$ & (Nishiwaki et al., 2006) \\
\hline Spectra & (Li et al., 1998) \\
\hline
\end{tabular}

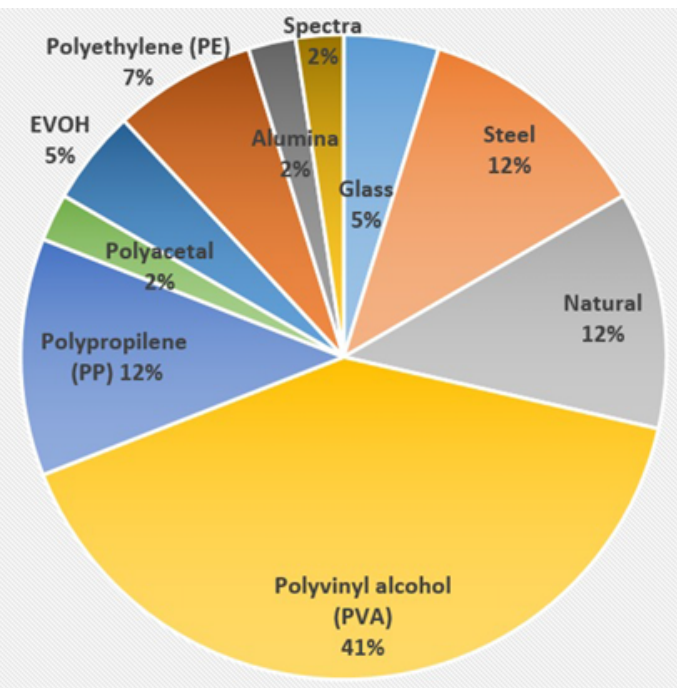

Fig. 1. Distribution of Fiber Materials Used in the Self-healing Investigations
Table 2. Classification of Self-healing Researches on Fiber Reinforced Cementitious Composites

\begin{tabular}{|c|c|c|}
\hline $\begin{array}{c}\text { Type of } \\
\text { cementitious } \\
\text { composite }\end{array}$ & $\begin{array}{l}\text { Type of } \\
\text { healing }\end{array}$ & References \\
\hline \multirow[t]{2}{*}{$\begin{array}{c}\text { FRCC } \\
\text { (Section 2.1) }\end{array}$} & $\begin{array}{l}\text { Autogenous } \\
\text { (Section } \\
2.1 .1 \text { ) }\end{array}$ & $\begin{array}{l}\text { (Snoeck and De Belie, 2015a) } \\
\text { (Van Tittelboom and De Belie, 2013b) } \\
\text { (Sanjuán } \text { et al., 1997) } \\
\text { (Nishiwaki } \text { et al., 2012) } \\
\text { (Van Tittelboom and De Belie, 2013b) } \\
\text { (Martinelli et al., 2015) } \\
\text { (Snoeck and De Belie, 2012) } \\
\text { (Snoeck et al., 2015b) } \\
\text { (Mihashi and Nishiwaski, 2012) } \\
\text { (Nishiwaki et al., 2014) } \\
\text { (Homma et al., 2009) } \\
\text { (Schlangen and Sangadji, 2013b) } \\
\text { (Schlangen et al., 2010) } \\
\text { (Tang et al., 2015) }\end{array}$ \\
\hline & $\begin{array}{c}\text { Engineered } \\
\text { (Section } \\
2.1 .2 \text { ) }\end{array}$ & $\begin{array}{l}\text { (Snoeck and De Belie, 2015a) } \\
\text { (Van Tittelboom and De Belie, 2013b) } \\
\text { (Snoeck et al., 2014) } \\
\text { (Ferrara et al., 2015b) } \\
\text { (Snoeck et al., 2016) } \\
\text { (Nishiwaki } \text { et al., 2015) } \\
\text { (Mihashi and Nishiwaski, 2012) } \\
\text { (Schlangen and Sangadji, 2013b) } \\
\text { (Schlangen } \text { et al., 2010) } \\
\text { (Roig-Flores et al., 2015) } \\
\text { (Tang et al., 2015) }\end{array}$ \\
\hline \multirow[t]{2}{*}{$\begin{array}{c}\text { HPFRCC } \\
\text { and ECC } \\
\text { (Section 2.2) }\end{array}$} & $\begin{array}{l}\text { Autogenous } \\
\text { (Section } \\
2.2 .1 \text { ) }\end{array}$ & $\begin{array}{l}\text { (Snoeck and De Belie, 2015a) } \\
\text { (Van Tittelboom and De Belie, 2013b) } \\
\text { (Li and Li, 2011) } \\
\text { (Kan et al., 2010) } \\
\text { (Ferrara et al., 2015a) } \\
\text { (Martinelli et al., 2015) } \\
\text { (Mihashi and Nishiwaski, 2012) } \\
\text { (Lv and Chen, 2014) } \\
\text { (Schlangen and Sangadji, 2013b) } \\
\text { (Schlangen et al., 2010) } \\
\text { (Yang et al., Li, 2009) } \\
\text { (Garas et al., 2009) } \\
\text { (Yildirim et al., 2015b) } \\
\text { (Kim et al., 2014) } \\
\text { (Qian S., et al., 2009) } \\
\text { (Tang et al., 2015) }\end{array}$ \\
\hline & $\begin{array}{l}\text { Engineered } \\
\text { (Section } \\
2.2 .2 \text { ) }\end{array}$ & $\begin{array}{l}\text { (Snoeck and De Belie, 2015a) } \\
\text { (Van Tittelboom and De Belie, 2013b) } \\
\text { (Sahmaran et al., 2015) } \\
\text { (Wu et al., 2012) } \\
\text { (Mihashi and Nishiwaski, 2012) } \\
\text { (Özbay et al., 2013) } \\
\text { (Sahmaran and Li, 2008) } \\
\text { (Lv and Chen, 2014) } \\
\text { (Schlangen and Sangadji, 2013b) } \\
\text { (Schlangen et al., 2010) } \\
\text { (Kim and Schlangen, 2011) } \\
\text { (Li et al., 1998) } \\
\text { (Tang et al., 2015) }\end{array}$ \\
\hline
\end{tabular}

in Table 2.

Self-healing in concrete improves permeability and can also provide recovery of mechanical properties. Different authors tried to define the crack width threshold for "complete" autogenous healability /sealability because of the crack filling which is also likely to improve the fiber/matrix bond strength across the crack (Homma et al., 2009), (Nishiwaki et al., 2014), (Sanjuán et al., 
Table 3. Variables and conditioning environments for self-healing of FRCC elements

\begin{tabular}{|c|c|c|c|c|}
\hline Reference & $\begin{array}{c}\text { Age of } \\
\text { precraking }\end{array}$ & Variables & Conditioning environments & $\begin{array}{c}\text { Specimen } \\
\text { (shape and size) }\end{array}$ \\
\hline $\begin{array}{l}\text { (Snoeck et al., } \\
\text { 2014)* }\end{array}$ & 28 days & $\begin{array}{l}\text { Volume of fibers ( } 1 \text { and } 2 \%) \text {; mass } \%(\mathrm{~m} \%) \text { of } \\
\text { cement weight }(0,0.5,1,2 \text { or } 4) \text {; cracking test } \\
\text { (4point or splitting); curing method (wet/dry } \\
\text { cycles, relative humidity (different levels); type } \\
\text { of specimen; two types of SAP (A: copolymer of } \\
\text { acrylamide and sodium acrylate or B: cross- } \\
\text { linked potassium salt polyacrylate). }\end{array}$ & $\begin{array}{l}\text { Samples were cured for } 28 \text { days } \\
\text { under } 3 \text { different conditions: } \\
\text { a) Wet ( } 1 \text { day)/dry ( } 1 \text { day) cycles } \\
\text { at a relative humidity (RH) of } \\
60 \% \text { b) RH }>90 \% \text {. } \\
\text { c) } \mathrm{RH}=60 \% \text {. }\end{array}$ & Prisms $(15 \times 40 \times 160 \mathrm{~mm})$ \\
\hline $\begin{array}{l}\text { (Nishiwaki et al., } \\
\text { 2012) }\end{array}$ & 7 days & $\begin{array}{l}\text { Type of specimen; type of test (3-p bending } \\
\text { test; uniaxial tension test; permeability test); } \\
\text { time of immersion in water; number of cycles } \\
\text { of water immersion ( } 1 \text { or } 2 \text { ). }\end{array}$ & Water immersion & $\begin{array}{c}\text { Prisms }(40 \times 40 \times 160 \mathrm{~mm}) \\
\text { Plates } \\
(85 \times 85 \times 30 \mathrm{~mm})\end{array}$ \\
\hline $\begin{array}{l}\text { (Ferrara et al., } \\
\text { 2015b)* }\end{array}$ & 2 and 28 days & $\begin{array}{l}\text { Different mix designs with different amount } \\
\text { and type of steel fibers; } 6 \text { different exposure } \\
\text { conditions (immersion in water at } 15 \text { or } 30^{\circ} \mathrm{C} \text {; } \\
\text { permanent contact of cracked surface with } \\
\text { water; dry indoor conditions; humid con- } \\
\text { trolled environment; wet and dry week cycles); } \\
\text { different conditioning periods; different pre- } \\
\text { crack levels; notched or un-notched speci- } \\
\text { mens prior to bending test. }\end{array}$ & $\begin{array}{l}\text { Crystalline admixtures. Expo- } \\
\text { sures: immersion in water at } \\
15 \text { or } 30^{\circ} \mathrm{C} \text {; permanent con- } \\
\text { tact of cracked surface with } \\
\text { water; dry indoor conditions; } \\
\text { humid controlled environment; } \\
\text { wet and dry week cycles. }\end{array}$ & $\begin{array}{c}\text { Cylinders } \\
(\varnothing 150 \times 300 \mathrm{~mm}) \\
\text { Prisms notched } \\
(150 \times 150 \times 600 \mathrm{~mm}) \\
\text { Prisms unnotched } \\
(50 \times 100 \times 500 \mathrm{~mm})\end{array}$ \\
\hline $\begin{array}{l}\text { (Snoeck et al. } \\
\text { 2016)* }\end{array}$ & 28 days & $\begin{array}{l}\text { Two mixes: with/without SAP } \\
\text { Different levels of relative humidity }\end{array}$ & $\begin{array}{l}\text { Specimens were stored at dif- } \\
\text { ferent relative humidity }(\mathrm{RH}) \\
\text { values: } \\
\text { a) } \mathrm{RH}=60 \% \text {. } \\
\text { b) } \mathrm{RH}>90 \% \text {. } \\
\text { c) wet/dry cycles }(1 \mathrm{~h} \text { in water } \\
\text { and } 23 \mathrm{~h} \text { at } 0 \% \mathrm{RH}) \text {. } \\
\text { The temperature was always } \\
20 \pm 2^{\circ} \mathrm{C} \text {. The two reference sam- } \\
\text { ples without SAPs were only } \\
\text { stored in a RH }>90 \% \text { and in } \\
\text { wet/dry cycles. }\end{array}$ & $\begin{array}{l}\text { Cylinders } \\
(Ø 6 \times 10 \mathrm{~mm})\end{array}$ \\
\hline $\begin{array}{l}\text { (Snoeck and De } \\
\text { Belie, 2012) }\end{array}$ & 28 days & $\begin{array}{l}\text { Type of fibers (CF, TF, PVA); } \\
\text { Amount of fibers }(\mathrm{v}=0.5,1,2 \%) ; \\
\text { Superplasticizer contents }\left(5,7.5,10,15 \mathrm{~kg} / \mathrm{m}^{3}\right) \text {; } \\
\text { With or without cracking. }\end{array}$ & $\begin{array}{l}\text { After cracking: } \\
\text { wet/dry cycles at } 20^{\circ} \mathrm{C} \text {. } \\
(1 \text { day in water; then } \mathrm{RH}=60 \%)\end{array}$ & $\begin{array}{c}\text { Prisms } \\
(160 \times 40 \times 15 \mathrm{~mm})\end{array}$ \\
\hline $\begin{array}{l}\text { (Snoeck et al., } \\
\text { 2015b) }\end{array}$ & 28 days & $\begin{array}{l}\text { Type of fibers: synthetic (PVA fibers -used as } \\
\text { reference-) and natural: technical flax (TF), } \\
\text { cottonised flax (CF), non-retted hemp (NH) } \\
\text { and slightly-retted hemp (SH). } \\
\text { Different fiber contents: } 0.5,1,1.5 \text { or } 2 \% \text {. }\end{array}$ & Wet/dry cycles & $\begin{array}{c}\text { Prisms } \\
(160 \times 40 \times 10 \mathrm{~mm})\end{array}$ \\
\hline $\begin{array}{l}\text { (Nishiwaki et al., } \\
\text { 2015)* }\end{array}$ & 28 days & $\begin{array}{l}\text { Different degrees of saponification for PVA } \\
\text { fibers: } 96 \% \text { (PVA-A) and 99\% (PVA-F); dif- } \\
\text { ferent concretes (without fibers, PVA-F fibers } \\
\text { or the combination of PVA-A and PVA-F) }\end{array}$ & $\begin{array}{l}\text { Freeze/thaw cycles according } \\
\text { to the JIS A } 1148 \text { (ASTM C } \\
666-A) \text { method. }\end{array}$ & $\begin{array}{c}\text { Prisms } \\
(40 \times 40 \times 160 \mathrm{~mm})\end{array}$ \\
\hline $\begin{array}{l}\text { (Nishiwaki et al., } \\
\text { 2014) }\end{array}$ & 7 days & Type and volume of fibers & Immersion in water & $\begin{array}{c}\text { Plates } \\
(85 \times 85 \times 30 \mathrm{~mm})\end{array}$ \\
\hline $\begin{array}{c}\text { (Homma et al., } \\
\text { 2009) }\end{array}$ & 7 days & $\begin{array}{l}\text { Type of fibers (PE, SC or both); } \\
\text { Volume of fibers }(0.75 \text { or } 1.5 \%) \text {. }\end{array}$ & Immersion in water & $\begin{array}{c}\text { Plates } \\
(75 \times 75 \times 25 \mathrm{~mm})\end{array}$ \\
\hline $\begin{array}{l}\text { (Roig-Flores et al., } \\
2015)^{*}\end{array}$ & 2 days & $\begin{array}{l}\text { Crystalline admixture dosage: } 0 \% \text { (control } \\
\text { specimens), } 4 \% \text { by the weight of cement (CA } \\
\text { specimens). }\end{array}$ & $\begin{array}{l}\text { Self-healing exposure: water } \\
\text { immersion (WI), water contact } \\
\text { (WC), humidity chamber (HC) } \\
\text { and air exposure at laboratory } \\
\text { conditions (AE). }\end{array}$ & $\begin{array}{c}\text { Cylinders } \\
(Ø 150 \times 300 \mathrm{~mm})\end{array}$ \\
\hline
\end{tabular}

Note: All references refer to "autogenous healing" except those market with an asterisk (*) which correspond to "engineered healing"

1997), (Edvarsen, 1999).

Different authors observed complete sealing/healing cracks for crack widths up to 200-300 $\mu \mathrm{m}$. Anyway, independent of the type of damage exposure and the healing/sealing duration, in order to reach a complete crack closure cracks should be narrower or not wider than $50 \mu \mathrm{m}$ (Edvarsen, 1999), (Aldea et al., 2000), (Jacobsen and Sellevold, 1995), (Reinhardt and Jooss,
2003), (Snoeck and De Belie, 2012), (Nishiwaki et al., 2014).

It is evident that such fine crack widths can only be guaranteed when dispersed fiber reinforcement is used in a concrete mixture which has henceforth motivated, in the last five years or so, a huge flourishing of investigation on the self-healing capacity of FRCCs.

Some investigations showed that healing efficiency does not 
depend on the type of fibers used (Snoeck and De Belie, 2012). The factors that affect self-healing capability in FRCC are: geometrical properties of crack surface such as roughness, complexity and continuity (Nishiwaki et al., 2012), initial crack width (Snoeck and De Belie, 2012) and fiber dispersion due to different age of precracking and different environmental exposures. Specifically, although younger samples have more unhydrated cement particles and therefore, a higher self-healing capacity is expected compared older samples, it was observed that mature concretes have an improved fiber/matrix interfacial bond. Therefore, those older concretes had a better distributed cracking with finer cracks, which facilitates self-healing (Kan et al., 2010).

Table 3 identifies those factors for each research considered in this paper. Specifically, Table 3 shows: age of precracking, main variables of the research (such as type and amount of fibers), conditioning environments and shape and size of the specimens tested. It can be observed that most researches related to autogenous healing in FRC precracked at a concrete age of 7 or 28 days. Interestingly the investigations done by the research team of Nishiwaki precracked at 7 days and subjected the specimens (prisms but mainly plates) to water immersion, whereas the research group of Snoeck precracked at 28 days and after cracking subjected their specimens (prisms) to wet/dry cycles.

FRC reinforced with synthetic fibers have shown higher selfhealing capability, because these fibers do not only control crack width but also, thanks to their high polarity, promote chemical precipitation of self-healing products which improve water tightness (Nishiwaki et al., 2012). Flax fibers also proved to be a good substitute of synthetic fibers (Snoeck and De Belie, 2012).

A through crack compressive stress greatly favors crack healing and enhance the mechanical performance (Ferrara et al., 2015b; 2017a; 2017b).

Table 4. Techniques Used to Examine Crack Healing in FRCC Elements

\begin{tabular}{cl}
\hline $\begin{array}{c}\text { Technique used to examine } \\
\text { crack healing }\end{array}$ & \multicolumn{1}{c}{ Reference } \\
\hline & (Snoeck et al., 2014)* \\
(Nishiwaki et al., 2012) & (Ferrara et al., 2015b)* \\
Microscope & (Snoecket al., 2016)* \\
(Snoeck and De Belie, 2012) & (Snoeck et al., 2015b) \\
(Nishiwaki et al., 2014) & (Homma et al., 2009) \\
& (Roig-Flores et al.,2015)* \\
\hline Environmental scanning electron & (Snoeck et al., 2016)* \\
microscope (ESEM) & (Snoeck et al., 2014)* \\
\hline & (Ferrara et al., 2015b)* \\
Image analysis & (Snoeck et al., 2016)* \\
& (Roig-Flores et al., 2015)* \\
\hline Energy-dispersive X-ray & (Snoeck et al., 2016)* \\
spectroscopy (EDX) & (Homma et al., 2009) \\
\hline Raman Spectroscopy & (Snoeck et al., 2014)*
\end{tabular}

Note: All references refer to "autogenous healing" except those market with an asterisk $(*)$ which correspond to "engineered healing"
Table 5. Techniques Used to Verify Healing Recovery in FRCC Elements Against Environmental and Mechanical Actions

\begin{tabular}{|c|c|c|}
\hline Type of action & $\begin{array}{l}\text { Technique used to } \\
\text { verify recovery }\end{array}$ & Reference \\
\hline \multirow[t]{6}{*}{ Environmental } & Permeability & $\begin{array}{l}\text { (Snoeck et al., 2014)* } \\
\text { (Nishiwaki et al., 2012) } \\
\text { (Ferrara et al., 2015b)* } \\
\text { (Nishiwaki et al., 2014) } \\
\text { (Homma et al., 2009) } \\
\text { (Roig-Flores et al., 2015)* }\end{array}$ \\
\hline & Capillary water absorption & (Snoeck et al., 2014)* \\
\hline & $\begin{array}{l}\text { Resistance against } \\
\text { freeze-thaw cycles }\end{array}$ & (Nishiwaki et al., 2015)* \\
\hline & Electrochemical tests & (Sanjuán et al., 1997) \\
\hline & Linear polarization method & (Sanjuán et al., 1997) \\
\hline & $\begin{array}{l}\text { Mercury intrusion } \\
\text { porosimetry (MIP) }\end{array}$ & (Nishiwaki et al., 2015)* \\
\hline \multirow[t]{6}{*}{ Mechanical } & $\begin{array}{l}\text { Regain in strength and } \\
\text { stiffness }\end{array}$ & $\begin{array}{l}\text { (Ferrara } \text { et al., 2015b)* } \\
\text { (Snoeck and De Belie, 2012) } \\
\text { (Snoeck et al., 2015b) } \\
\text { (Nishiwaki et al., 2014) } \\
\text { (Homma et al., 2009) }\end{array}$ \\
\hline & $\begin{array}{l}\text { Recovery of Young } \\
\text { Modulus }\end{array}$ & $\begin{array}{l}\text { (Nishiwaki et al., 2015)* } \\
\text { (Snoeck and De Belie, 2012) } \\
\text { (Snoeck et al., 2015b) }\end{array}$ \\
\hline & Bending test & $\begin{array}{l}\text { (Snoeck et al., 2014)* } \\
\text { (Ferrara } \text { et al., 2015b)* } \\
\text { (Snoeck and De Belie, 2012) } \\
\text { (Snoeck et al., 2015b) }\end{array}$ \\
\hline & Tensile/splitting test & $\begin{array}{l}\text { (Snoeck et al., 2014)* } \\
\text { (Nishiwaki et al., 2012) } \\
\text { (Snoeck et al., 2015b) } \\
\text { (Nishiwaki et al., 2014) } \\
\text { (Homma et al., 2009) }\end{array}$ \\
\hline & Strain capacity & $\begin{array}{l}\text { (Ferrara et al., 2015b)* } \\
\text { (Snoeck et al., 2014)* } \\
\text { (Snoeck and De Belie, 2012) } \\
\text { (Snoeck et al., 2015b) }\end{array}$ \\
\hline & Energy absorption & $\begin{array}{l}\text { (Nishiwaki et al., 2014) } \\
\text { (Snoeck and De Belie, 2012) }\end{array}$ \\
\hline
\end{tabular}

Note: All references refer to "autogenous healing" except those market with an asterisk $(*)$ which correspond to "engineered healing"

From the literature survey it was also observed that several different techniques have been employed to study the selfhealing capacity of FRC, which have been summarized in Table 4.

Also, a differentiation has been made in Table 5 between techniques to verify recovery against environmental or mechanical actions, used to verify crack sealing or crack healing respectively. In the former case FRC permeability tests are almost the unique employed technique while for recovery against mechanical actions the regain in strength by mechanical testing is the preferred choice.

\subsubsection{Engineered Healing of Ordinary FRCC}

Engineered healing capability is due to the addition of tailored admixtures to the concrete mix with the explicit purpose of favoring/activating the healing reactions. The background to engineered additions for self-healing could be the fly ashes and blast furnace slags.

The main investigations on engineered healing of ordinary 
FRCC are summarized in Table 2.

Nishiwaki et al. (2015) evaluated the self-healing capability of FRCCs adding silica fume in the mix. In this case, PVA fibers were used and the objective was to study the self-healing capability against freeze/thaw cycles. After this investigation, it was concluded that the Relative Dynamic Young's-modulus (RDYM) of FRC was affected because of the freeze/thaw cycles but it was recovered by the self-healing effect after water curing. The pozzolanic reaction of silica fume could accelerate the filling up of cracks. It was observed that pore volume decreased when silica fume was added, nevertheless the combination of silica fume and fibers resulted preferred for enhancing the selfhealing effect (Nishiwaki et al., 2015).

Tailored additions such as crystalline admixtures and Superabsorbent Polymers (SAP) have been also recently used on larger scale to enhance the self-healing capability. Crystalline admixtures have mainly used by Ferrara et al. (2014a; 2015b; 2016a) and Roig-Flores et al. (2015) and SAP mainly by Snoeck et al. (see Table 3). Crystalline admixtures are a special type of permeability reducing admixtures as reported by the ACI Committee 212 (ACI Committee 212, 2010) and consist of active chemicals which react with water and cement hydration products to form healing products that precipitates in the cracks. Their use promotes the healing of existing cracks and thus, enhances both the recovery of water tightness and recovery of post-cracking load bearing capacity (Ferrara et al., 2015b) guaranteeing a complete sealing of cracks up to $500 \mu \mathrm{m}$ (which is in the range of allowable crack widths for SLS of FRC structures). All the researches on engineering healing of ordinary FRC precracked at a concrete age of 28 days, although Ferrara et al. also precracked at early ages ( 2 days) as it is showed in Table 3.

As for autogenous healing of FRC, a through crack compression stress, favors the sealability and healability (Ferrara et al., 2015b). The techniques employed to examine crack engineered healing in FRCs were more varied than the techniques used for autogenous healing. As for autogenous practically all the investigations used microscope observations. Moreover, in the case of engineered healing other techniques were also employed such as environmental scanning electron microscope, image analysis and thermogravimetric analysis (Table 4). On the other hand, in Table 5 are presented the environmental and mechanical techniques used to verify crack sealing/healing, including: permeability, capillary water absorption, resistance against freezethaw cycles and Mercury Intrusion Porosimetry (MIP), as well as the same mechanical techniques used for autogenous healing.

With reference to the influence of exposure conditions (see conditioning environments in Table 3 ), recent investigations while confirming the importance of the presence of water- have also shown that, in order of increasing sealing/healing rates, the following holds: air exposure, humid chamber, water contact, water immersion.

For the former exposure condition it can be also claimed that crystalline admixtures can effectively counteract the shrinkage.

As for the effect of exposure/conditioning duration it has been shown that crystalline admixtures may promote a continuous healing (Ferrara et al., 2015b) and recovery of performance even for longer conditioning times (results up to 9 months are available). This does not seem to be the case for autogenous healing of FRC which showed, at least with reference to the surveyed studies analyzed, a higher effectiveness in earlier exposure times, with no future improvements after intermediate exposure times (3 months).

Specimens stored under water immersion achieve the highest self-healing rates and obtained complete healing in some cases. The exposures in order of increasing permeability healing rate are: air exposure, humidity chamber, water contact and water immersion (Roig-Flores et al., 2015).

With reference to investigations which used Superabsorbent Polymers (SAP) as healing triggered it was found that introducing 1 $\mathrm{m} \%$ of superabsorbent polymers gave the best results: no reduction of mechanical properties compared to the reference concrete and an optimal self-sealing capacity. The combination of SAP with fibers lead to improved self-healing (Snoeck et al., 2014). Recently, it has been shown that healing capacity depends on crack depth. If SAPs are added, the extend of healing will be more substantial (Snoeck et al., 2016). The advantage of SAPs is that they can be useful in regions with almost no rain can penetrate or strongly discontinuous presence of water, because they are able to absorb even the least amount of moisture and provide it to the mix for self-healing process (Snoeck et al., 2014).

\subsection{Self-healing of HPFRCC}

\subsubsection{Autogenous Healing of HPFRCC}

In this section and in Table 2, investigations regarding to autogenous healing of HPFRCC specimens, a great part of which, as it can be seen, has focused on a special category of these advanced cement based materials known as Engineered Cementitious Composites (ECCs).

The precracking age of the investigated HPFRCC mixes (see Table 6) shows a higher variability, ranging from 7 days Garas et al. (2009) to 28-30 days Li and Li (2011), Qian et al. (2009), Ferrara et al. (2015a; 2016b) and even older precracking ages: 23 months Kim et al. (2014) and 6 months Yang et al. (2009) and Yildirim et al. (2015b). Also the variables which have been analyzed in the tests, conditioning environments and the types of specimens used are included in Table 6.

The techniques used to examine autogenous crack healing in HPFRCCs were: Microscope, environmental scanning electron microscope, image analysis, energy-dispersive X-ray spectroscopy and resonant frequency.

As for FRCs (Table 5), also for HPFRCCs (both environmental and mechanical techniques) have been used to verify closure of cracks and its effects on the material performance (Table 8).

Going into the research conducted it should be emphasized the following:

In 2014, Kim et al. observed that the use of fine silica sand in 
HPFRCC with high strength steel fibers led to rapid healing owing to very fine cracks with width lower than $20 \mu \mathrm{m}$ (Kim et al., 2014).

As reminded in the introduction the composition of HPFRCCs is naturally conduced to self-healing because of the high cement/ binder contents and low water/binder ratio. This leaves a lot of unhydrated binder particles, which upon cracking are exposed to outdoor environment and can react with water/air moisture, etc. and activate the healing reactions.

Recently, Ferrara et al. (2016b; 2016c) have thoroughly investigated autogenous self-healing capacity of HPFRCCs under different exposure conditions (water immersion, open air, humid and dry environment, wet/dry cycles) and for exposure durations up to two years. Effects of self-healing on the recovery of different mechanical properties have been investigated, such as peak strength, ductility, stiffness, toughness, etc. and correlated to the amount of visually analyzed crack closure.

Interestingly under favorable exposure conditions (water immersion, high humidity and even wet/dry cycles) healing of cracks continued even for longer exposure times, even if with slower rates. In some cases, cracks up to $0.5 \mathrm{~mm}$ width were completely repaired.

In general, a recovery of strength and stiffness was accompanied by a worsened performance in terms of ductility.

Also, Snoeck carried out tests done up to one year for different mixture compositions with supplementary cementitious materials (Snoeck D., 2015c).

Recently, in 2015 Ferrara et al. studied the efficacy of natural fibers (specifically sisal fibers) to promote and enhance selfhealing capability in HPFRCC. Natural fibers create a porous network through which the moisture can be distributed in the cementitious matrix. This activates the delayed hydration reactions which make possible the healing of the cracks together with carbonation reactions. Both these phenomena promote crack closure and reconstruct through-crack material continuity. It was observed that the strength of a healed crack could be even higher than the corresponding to the original matrix material. Moreover, the recovery of the load bearing capacity was attributable totally to crack healing and not to bulk delayed hydration. Also, a high recovery was observed for wet/dry cycles. It seems that this exposure conditions enhances the role of natural fibers on the healing process since they absorb water during the wet cycle and then they release it during the dry one. Comparison with HPFRCCs containing steel fibers only highlighted that natural fibers also accelerate the healing process (Ferrara et al., 2015a).

In 2009, Yang et al. studied the self-healing of ECC specimens subjected to wet/dry cycles. The level of damage was determined by means of resonant frequency tests, which ECC specimens recovered $76-100 \%$ of their initial resonant frequency values. Also, tensile tests were performed and a recovery of nearly $100 \%$ of the virgin strain capacity was observed. It was concluded that, to observe self-healing, crack widths must be lower than $150 \mu \mathrm{m}$ (preferably lower than $50 \mu \mathrm{m}$ ). To obtain self-healing benefits, only 4-5 wet/dry cycles are needed. Also, the influence of temperature during the wet/dry cycles was analyzed. Higher temperature during self-healing process can lead to an increase of the ultimate strength and a light decrease of tensile strain capacity of ECC. Finally, self-healed ECC remains ductile (Yang et al., 2009).

Yildirim et al. (2015a) studied the effects of sustained mechanical loading on self-healing behavior. It was concluded that, even under progressively increasing sustained mechanical loading, modulus of rupture after healing resulted higher than the original values although the amount of improvement depended on the mineral admixture used (Yildirim et al., 2015a). Li et al. (2011) focused the investigation on durability, specifically corrosion resistance under combined mechanical loading and aggressive chloride conditions. Tensile ductility and microcracking behavior are necessary for achieving structural durability. After this investigation it was ensured that self-healing in ECC under chloride exposure, such as severe marine environmental conditions, can guarantee recovery of initial material stiffness and tensile strain capacity, durability, ductility and crack-control capacity ( $\mathrm{Li}$ and $\mathrm{Li}, 2011$ ).

Snoeck and De Belie studied the repeatability of autogenous healing in strain-hardening fiber-reinforced cementitious materials by using SAPs by measuring their mechanical properties after they were subjected to two cycles of loading under bending tests. The healed specimens regained up to $75 \%$ of their mechanical properties and, after a second reloading specimens reached a partial additional regain up to $66 \%$ in mechanical properties (Snoeck and De Belie, 2015d).

\subsubsection{Engineered Healing of HPFRCC}

Looking at the specimen precracking age (Table 6) in the tests to analyze engineered healing of HPFRCC it is clear that almost all the specimens were precracked at 28 days. Only some authors precracked at earlier ages: 3 days (Sahmaran et al., 2015), 7 days (Kim and Schlangen, 2011) and 15 days (Li et al., 1998).

It is worth highlighting that, for the cases analyzed in this section, specimens were generally precracked at later ages than for previously examined ones (Table 6). In Table 7 the techniques used to examine crack healing are showed.

$\mathrm{Li}$ (Li et al., 1998) was one of the pioneers who studied engineered healing of HPFRCC and ECC applying different techniques to verify healing recovery against mechanical actions (Table 8). In 2008 Sahmaran and Li (2008) studied the durability of ECC under highly alkaline environments observing that specimens made of ECC with Class-F fly ash showed lower ductility and tensile strength. ECC maintained multicracking behavior and tensile strain capacity higher than 2\% (it means around 200 times that of ordinary concretes and ordinary FRCs). Tests indicated self-healing of microcracked ECCs, which could still achieve important tensile stresses and strains almost restoring their original stiffness. Tests also showed that ECC (both virgin and cracked), remain durable despite exposure to high alkaline environments (Sahmaran and Li, 2008). Sahmaran et al. (2008) 
Table 6. Variables and Conditioning Environments for Self-healing of HPFRCC and ECC Elements

\begin{tabular}{|c|c|c|c|c|}
\hline Reference & $\begin{array}{c}\text { Age of } \\
\text { precraking }\end{array}$ & Variables & Conditioning environments & Specimen (shape and size) \\
\hline (Li and $\mathrm{Li}, 2011$ ) & 28 days & $\begin{array}{l}\text { Different preloaded tensile strain levels } \\
(0.5,1,1.5 \%) \text {; } \\
\text { Specimens immersed in chloride solution } \\
\text { for } 30,60,90 \text { days }\end{array}$ & $\begin{array}{l}\text { Cured in air and, } \\
\text { chloride solution } \\
\text { (immersion in } 3 \% \mathrm{NaCl} \text { solu- } \\
\text { tion) }\end{array}$ & $\begin{array}{c}152.4 \times 76.2 \times 12.7 \mathrm{~mm} \\
(\text { for tensile tests) } \\
305 \times 76 \times 38 \mathrm{~mm} \\
\text { (for bending and compact ten- } \\
\text { sion tests) } \\
10 \times 10 \times 0.5 \mathrm{~mm} \\
(\text { for pull-out tests) }\end{array}$ \\
\hline (Kan et al., 2010) & 3 and 90 days & $\begin{array}{l}\text { Different crack widths (microcrack damages) } \\
\text { corresponding to these tensile deforma- } \\
\text { tions levels: } 0.3,0.5,1.0 \text { and } 2.0 \% \text {. }\end{array}$ & $\begin{array}{l}\text { Wet/dry cycles } \\
(24 \text { h wet }+24 \text { h dry })\end{array}$ & $300 \times 76 \times 12.5 \mathrm{~mm}$ \\
\hline (Ferrara et al., 2015a) & 30 days & $\begin{array}{l}\text { Two different amount of fibers (steel fibers } \\
=\text { sisal fibers }=100 \mathrm{~kg} / \mathrm{m}^{3} ; \text { steel fibers }=50 \mathrm{~kg} / \\
\left.\mathrm{m}^{3} \text { and sisal fibers }=7 \mathrm{~kg} / \mathrm{m}^{3}\right) ; \text { specimens } \\
\text { with different fiber orientation (longitudinal; } \\
\text { transversal); four different environments } \\
\text { (immersion in water; dry; moist; wet and dry } \\
\text { cycles); exposure duration ( } 3 \text { or } 6 \text { months). }\end{array}$ & $\begin{array}{l}\text { Immersion in water; } \\
\text { dry; moist; wet and dry cycles. }\end{array}$ & $30 \times 100 \times 500 \mathrm{~mm}$ \\
\hline $\begin{array}{l}\text { (Sahmaran et al., } \\
\text { 2015)* }\end{array}$ & 3 and 28 days & $\begin{array}{l}2 \text { different ECC mixtures: one incorporat- } \\
\text { ing Class F fly ash, other with ground- } \\
\text { granulated blast furance slag. //Different } \\
\text { age of concrete before cyclic preloading ( } 3 \text { or } \\
28 \text { days old). //Preloading level (virgin or } \\
\text { preloaded up to } 70 \% \text { ). //Different number } \\
\text { of preloading cycles. }\end{array}$ & $\begin{array}{l}\text { Wet/dry cycles (immersion in } \\
\text { water at } 23^{\circ} \mathrm{C} \text { for } 24 \text { hours and } \\
\text { drying in a laboratory medium } \\
\text { at } 50 \% \text { relative humidity and } \\
23^{\circ} \mathrm{C} \text { for } 24 \text { hours). }\end{array}$ & $\begin{array}{c}360 \times 50 \times 75 \mathrm{~mm} \\
\text { (for bending tests) } \\
\varnothing 150 \times 300 \mathrm{~mm} \\
\text { (for resonant frequency tests) } \\
\varnothing 100 \times 200 \mathrm{~mm} \\
\text { (for permeability tests) } \\
\varnothing 100 \times 50 \mathrm{~mm} \\
\text { (RCPT tests) }\end{array}$ \\
\hline (Özbay et al., 2013)* & 28 days & $\begin{array}{l}\text { Two ECC mixtures with } 2 \text { different levels } \\
\text { of fly ash content ( } 55 \text { and } 70 \% \text { FA); two } \\
\text { different exposure regimes (continuous air } \\
\text { and continuous water); two different expo- } \\
\text { sure periods (short and long, respectively } \\
30 \text { or } 90 \text { days). }\end{array}$ & $\begin{array}{l}\text { Continuous air and immersion } \\
\text { in water. }\end{array}$ & $\begin{array}{c}360 \times 50 \times 75 \mathrm{~mm} \\
(\text { for bending tests) } \\
50 \times 50 \times 50 \mathrm{~mm} \\
(\text { for compressive tests) }\end{array}$ \\
\hline $\begin{array}{l}\text { (Sahmaran and Li, } \\
\text { 2008)* }\end{array}$ & 28 days & $\begin{array}{l}2 \text { alkali exposure conditions (in laboratory air } \\
\text { after } 7 \text { days moist curing or immersed in } \\
\left.\text { alkali solution at } 38^{\circ} \mathrm{C}\right) ; 2 \text { periods of immer- } \\
\text { sion in alkali solution ( } 30 \text { or } 90 \text { days); } \\
\text { uncracked or precracked ( } 2 \text { preloading strain } \\
\text { levels for uniaxial tensile tests: } 1 \text { or } 2 \% \text { ) spec- } \\
\text { imens. }\end{array}$ & $\begin{array}{l}2 \text { alkali exposure conditions: } \\
\text { - In laboratory air after } 7 \text { days } \\
\text { moist curing; } \\
\text { - Immersion in alkali solution } \\
\text { at } 38^{\circ} \mathrm{C} \text {. }\end{array}$ & $\begin{array}{c}152.4 \times 76.2 \times 12.7 \mathrm{~mm} \\
\text { (for tensile tests) } \\
\varnothing 75 \times 150 \mathrm{~mm} \\
(\text { for compressive tests) } \\
25 \times 25 \times 285 \mathrm{~mm} \\
\text { (for exposure alkaline envi- } \\
\text { ronment) }\end{array}$ \\
\hline $\begin{array}{l}\text { (Kim and Schlangen, } \\
2011)^{*}\end{array}$ & 7 and 28 days & $\begin{array}{l}3 \text { different mix proportions(PVA only, } \\
\text { PVA+SAP } 0.5 \% \text {, PVA+SAP } 1 \%) ; 2 \text { pre- } \\
\text { cracking ages ( } 7 \text { or } 28 \text { days); } 4 \text { curing con- } \\
\text { dition (A: cured in air; C: cyclic wet-dry; W: } \\
\text { water; R: cyclic wet-dry condition on pre- } \\
\text { cracked specimens and then cured again); } \\
\text { precracked specimen or not. }\end{array}$ & $\begin{array}{l}\text { - Cured in air: } 50 \% \mathrm{RH} \text { at } 20^{\circ} \mathrm{C} \text {; } \\
\text { - Wet/dry cycles: } \\
\text { immersion in water at } 20^{\circ} \mathrm{C} \\
\text { for } 1 \text { hour and drying for } 3 \\
\text { days; } \\
\text { - Water }\left(20^{\circ} \mathrm{C}\right) .\end{array}$ & $\begin{array}{c}120 \times 30 \times 10 \mathrm{~mm} \\
\text { (for } 4-\mathrm{p} \text { bending tests) }\end{array}$ \\
\hline (Yang et al., 2009) & 6 months & $\begin{array}{l}2 \text { different cyclic wetting and drying } \\
\text { regimes }\end{array}$ & $\begin{array}{l}2 \text { different wet/dry cycles: } \\
\text { 1) Immersion in water at } 20^{\circ} \mathrm{C} \\
\text { for } 24 \mathrm{~h} \text { and drying in labora- } \\
\text { tory air at } 21 \pm 1^{\circ} \mathrm{C} \text { for } 24 \mathrm{~h} \text {. } \\
\text { 2) Immersion in water at } 20^{\circ} \mathrm{C} \\
\text { for } 24 \mathrm{~h} \text {, oven drying at } 55^{\circ} \mathrm{C} \\
\text { for } 22 \mathrm{~h} \text {, and cooling in labora- } \\
\text { tory air at } 21 \pm 1^{\circ} \mathrm{C} \text { for } 2 \mathrm{~h} \text {. }\end{array}$ & $230 \times 76 \times 13 \mathrm{~mm}$ \\
\hline (Garas et al., 2009) & 7 days & $\begin{array}{l}2 \text { levels of stress/strength at loading: } 40 \text { or } \\
60 \% ; 2 \text { levels of curing temperature: } 23 \text { or } \\
90{ }^{\circ} \mathrm{C} \text {; mix without fibers or mix with } 2 \% \\
\text { of fibers. }\end{array}$ & $\begin{array}{l}\text { Different thermal treatment } \\
\text { temperatures: } \\
\text { 1) Specimens were stored in a } \\
\text { fog room at } 23^{\circ} \mathrm{C} \text { and } 100 \% \mathrm{RH} \\
\text { 2) Specimens were placed in an } \\
\text { environmental chamber at } 90^{\circ} \mathrm{C} \\
\text { and } 100 \% \mathrm{RH} \text { for the next } 48 \mathrm{~h} \text {. }\end{array}$ & $\varnothing 100 \times 380 \mathrm{~mm}$ \\
\hline (Li et al., 1998)* & 15 days & $\begin{array}{l}\text { Volume of fibers: } 0.01 \text { or } 0.02 \text {; Different } \\
\text { types of fibers (different diameter and length); } \\
2 \text { specimens (ESEM specimens and beams } \\
\text { for flexural tests); } 2 \text { sizes of hollow glass fiber } \\
\text { (custom-made for ESEM specimens and } \\
\text { commercial for flexural specimens). }\end{array}$ & $\begin{array}{l}\text { Water cured at room tempera- } \\
\text { ture for } 2 \text { weeks. }\end{array}$ & $\begin{array}{l}76.2 \times 101.6 \times 350.6 \mathrm{~mm} \\
(\text { for } 4-\mathrm{p} \text { bending tests }) \\
76.2 \times 38.1 \times 254 \mathrm{~mm} \\
(\text { for } 3-\mathrm{p} \text { bending tests })\end{array}$ \\
\hline
\end{tabular}


Table 6. Variables and Conditioning Environments for Self-healing of HPFRCC and ECC Elements

\begin{tabular}{|c|c|c|c|c|}
\hline Reference & $\begin{array}{c}\text { Age of } \\
\text { precraking }\end{array}$ & Variables & Conditioning environments & Specimen (shape and size) \\
\hline $\begin{array}{l}\text { (Yildirim et al., } \\
2015 \mathrm{~b})\end{array}$ & 180 days & $\begin{array}{l}4 \text { mixtures incorporating different mineral } \\
\text { admixtures ( } 3 \text { different types of fly ash and } \\
\text { ground granulated blast furnace slag. }\end{array}$ & $\begin{array}{l}\text { Water exposure during } 1 \text { month } \\
\text { (according to ASTM C 597) } \\
\text { Moist curing during } 150 \text { days }\end{array}$ & $360 \times 75 \times 50 \mathrm{~mm}$ \\
\hline (Kim et al., 2014) & 90 days & $\begin{array}{l}3 \text { types of steel fibers (smooth, hooked, } \\
\text { twisted); } 2 \text { types of sand with different } \\
\text { sizes (normal crushed sand, very fine silica } \\
\text { sand and fine silica sand); healing for } 3,7 \\
\text { and } 14 \text { days. }\end{array}$ & $\begin{array}{l}\text { Specimens were stored } \mathrm{n} \text { air or } \\
\text { water (with } \mathrm{pH} 7 \text { ) for } 3,7 \text {, and } \\
14 \text { days }\end{array}$ & $100 \times 100 \times 350 \mathrm{~mm}$ \\
\hline (Qian S., et al., 2009) & 28 days & $\begin{array}{l}2 \text { exposures (immersion in water or air } \\
\text { cured). // } 4 \text { different mixes // Bend until } \\
\text { final failure or bend to } 2.4 \mathrm{~mm} / / \text { Concrete } \\
\text { age: } 28 \text { (bending test) or } 56 \text { days (redo } \\
\text { bending). }\end{array}$ & Immersion in water and air cured. & $\begin{array}{c}40 \times 40 \times 40 \mathrm{~mm} \\
\text { (for compressive tests) } \\
120 \times 30 \times 10 \mathrm{~mm} \\
\text { (for 4-p bending tests and uni- } \\
\text { axial tests) }\end{array}$ \\
\hline
\end{tabular}

Note: All references refer to "autogenous healing" except those market with an asterisk (*) which correspond to "engineered healing"

Table 7. Techniques Used to Examine Crack Healing in HPFRCC and ECC Elements

\begin{tabular}{|c|c|}
\hline $\begin{array}{l}\text { Technique used to } \\
\text { examine crack healing }\end{array}$ & Reference \\
\hline $\begin{array}{c}\text { Microscope } \\
\text { (optical and digital) }\end{array}$ & $\begin{array}{l}\text { (Ferrara et al., 2015a) } \\
\text { (Sahmaran et al., 2015)* } \\
\text { (Özbay et al., 2013)* } \\
\text { (Sahmaran and Li, 2008)* } \\
\text { (Yang et al., 2009) } \\
\text { (Li et al., 1998)* } \\
\text { (Yildirim et al., 2015b) } \\
\text { (Kim et al., 2014) }\end{array}$ \\
\hline $\begin{array}{l}\text { Environmental scanning } \\
\text { electron microscope } \\
\text { (ESEM) }\end{array}$ & $\begin{array}{l}\text { (Kan et al., 2010) } \\
\text { (Özbay et al., 2013)* } \\
\text { (Sahmaran and Li, 2008)* } \\
\text { (Li et al., 1998)* } \\
\text { (Kim et al., 2014) } \\
\text { (Qian S., et al., 2009) }\end{array}$ \\
\hline Image analysis & (Kim et al., 2014) \\
\hline $\begin{array}{l}\text { Energy-dispersive X-ray } \\
\text { spectroscopy (EDX) }\end{array}$ & $\begin{array}{l}\text { (Kan et al., 2010) } \\
\text { (Özbay et al., 2013)* } \\
\text { (Yang et al., 2009) } \\
\text { (Qian S., et al., 2009) }\end{array}$ \\
\hline Resonant frequency & (Kan et al., 2010) \\
\hline
\end{tabular}

Note: All references refer to "autogenous healing" except those market with an asterisk $(*)$ which correspond to "engineered healing"

performed permeability and capillary water absorption tests to verify sealing of cracks. On the other hand, used compressive strength and tensile tests were used to verify regain in strength and stiffness and, therefore, to verify healing of cracks (Table 8).

Tests in ECC specimens with SAPs and the application of different mechanical techniques carried out by Kim and Schlangen showed that SAP maintain the water in the cracked zones and help the self-healing process. Specifically, they showed the possibilities of the promoted autogenous healing by means of SAPs, but lots of other research was performed as well, more funding the applicability of SAPs for stimulated autogenous healing. This stimulated (or promoted) healing can be put at the general healing as well if SAPs are not used (Kim and Schlangen, 2011).

In 2013, Özbay studied the effect of sustained flexural loading on the self-healing capability of two different ECC mixtures (each one with a different amount of Class-F fly ash). Specimens were immersed in water and exposed to air and they were subjected or not to sustained mechanical loads for up to 90 days (equal to $60 \%$ of the ultimate flexural strength). The main results of this investigation are: specimens immersed in water without sustained loads showed enhanced flexural stiffness and flexural deflection capacity recovery due to the presence of healing products in the cracks (Özbay et al., 2013). Those healing products are substances of hydration resulting from a calcium hydroxide reaction which is one of the most important mechanisms of selfhealing (Mihashi and De Leite, 2004). Calcium hydroxide reacts with carbon dioxide $\mathrm{CO}_{2}$ (atmosphere or dissolved in water) to obtain calcium carbonate. The chemical reaction is the following:

$$
\mathrm{Ca}^{2+}+\mathrm{CO}_{2}+\mathrm{H}_{2} \mathrm{O} \leftrightarrow \mathrm{CaCO}_{3}+2 \mathrm{H}^{+}
$$

Where $\mathrm{Ca}^{2+}$ are the calcium ions and $\left(\mathrm{CO}_{2}+\mathrm{H}_{2} \mathrm{O}\right)$ represent the external environment. All of these components react for obtaining calcium carbonate $\left(\mathrm{CaCO}_{3}\right)$. Inside the crack, calcium hydroxide $\left(\mathrm{Ca}(\mathrm{OH})_{2}\right)$ is dissolved in the water inside the crack and precipitate calcium ions at the crack surface.

$$
\mathrm{Ca}(\mathrm{OH})_{2} \leftrightarrow \mathrm{Ca}^{2+}+2 \mathrm{OH}^{-}
$$

On the crack surface, calcium carbonate will be formed due to the reaction of $\mathrm{CO}_{2}$ with Portlandite (calcium hydroxide) present in the concrete matrix and its amount will depend on the presence of $\mathrm{CO}_{2}$ :

$$
\mathrm{CO}_{2}+\mathrm{Ca}(\mathrm{OH})_{2} \leftrightarrow \mathrm{CaCO}_{2}+\mathrm{H}_{2} \mathrm{O}
$$

On the other hand, sustained loads shadowed the effects of self-healing and no-recovery (or even a worsening) of the properties was, in case, observed. This could be because sustained loads cause increases in the width of the preexisting cracks on ECC specimens (Özbay et al., 2013), obviously also as a function of the employed mix constituents and fiber types (some fibers being highly sensitive themselves to deformation under sustained stress).

Recently, Ferrara observed better self-healing responses, such 
Table 8. Techniques Used to Verify Healing Recovery in HPFRCC and ECC Elements Against Environmental and Mechanical Actions

\begin{tabular}{|c|c|c|}
\hline Type of action & $\begin{array}{l}\text { Technique used to } \\
\text { verify recovery }\end{array}$ & Reference \\
\hline \multirow[t]{6}{*}{ Environmental } & Permeability & $\begin{array}{l}\text { (Sahmaran et al., 2015)* } \\
\text { (Sahmaran and Li, 2008)* } \\
\text { (Yang et al., 2009) }\end{array}$ \\
\hline & Capillary water absorption & (Sahmaran and Li, 2008)* \\
\hline & $\begin{array}{c}\text { Resonant frequency } \\
\text { analysis }\end{array}$ & $\begin{array}{l}\text { (Kan et al., 2010) } \\
\text { (Sahmaran et al., 2015)* } \\
\text { (Yang et al., 2009) }\end{array}$ \\
\hline & Ultrasonic measurements & (Yildirim et al., 2015b) \\
\hline & $\begin{array}{l}\text { Resistance against } \\
\text { corrosion }\end{array}$ & $\begin{array}{l}\text { (Li and } \mathrm{Li}, 2011) \\
\text { (Kim et al., 2014) }\end{array}$ \\
\hline & Spectroscopy & $\begin{array}{l}\text { (Kan et al., 2010) } \\
\text { (Qian S., et al., 2009) }\end{array}$ \\
\hline \multirow[t]{9}{*}{ Mechanical } & $\begin{array}{l}\text { Regain in strength and } \\
\text { stiffness }\end{array}$ & $\begin{array}{l}\text { (Li and Li, 2011) } \\
\text { (Li et al., 1998)* } \\
\text { (Yang et al., 2009) } \\
\text { (Kan et al., 2010) } \\
\text { (Ferrara et al., 2015a) } \\
\text { (Sahmaran et al., 2015)* } \\
\text { (Özbay et al., 2013)* } \\
\text { (Sahmaran and Li, 2008)* } \\
\text { (Kim and Schlangen, 2011)* } \\
\text { (Yildirim et al., 2015b) } \\
\text { (Kim et al., 2014) } \\
\text { (Qian S., et al., 2009) }\end{array}$ \\
\hline & Fatigue resistance & (Kim and Schlangen, 2011)* \\
\hline & $\begin{array}{l}\text { Recovery of elastic } \\
\text { modulus }\end{array}$ & (Li et al., 1998)* \\
\hline & Compressive strength test & $\begin{array}{l}\text { (Özbay et al., 2013)* } \\
\text { (Sahmaran and Li, 2008)* } \\
\text { (Yildirim et al., 2015b) }\end{array}$ \\
\hline & $\begin{array}{l}\text { Bending test } \\
\text { (flexural test) }\end{array}$ & $\begin{array}{l}\text { (Ferrara et al., 2015a) } \\
\text { (Sahmaran et al., 2015)* } \\
\text { (Özbay et al., 2013)* } \\
\text { (Kim and Schlangen, 2011)* } \\
\text { (Li et al., 1998)* } \\
\text { (Yildirim et al., 2015b) } \\
\text { (Qian S., et al., 2009) }\end{array}$ \\
\hline & Tensile/splitting test & $\begin{array}{l}\text { (Li and } \mathrm{Li}, 2011) \\
\text { (Kan et al., 2010) } \\
\text { (Sahmaran et al., 2015)* } \\
\text { (Sahmaran and Li, 2008)* } \\
\text { (Yang et al., 2009) } \\
\text { (Garas et al., 2009) } \\
\text { (Li et al., 1998)* } \\
\text { (Kim et al., 2014) }\end{array}$ \\
\hline & Strain capacity & $\begin{array}{l}\text { (Li and } \mathrm{Li}, 2011) \\
\text { (Özbay et al., 2013)* } \\
\text { (Sahmaran and Li, 2008)* } \\
\text { (Yang et al., 2009) } \\
\text { (Li et al., 1998)* } \\
\text { (Kim et al., 2014) }\end{array}$ \\
\hline & $\begin{array}{l}\text { Energy absorption/ } \\
\text { toughness recovery }\end{array}$ & (Li and $\mathrm{Li}, 2011$ ) \\
\hline & Pullout tests & $\begin{array}{l}\text { (Li and } \mathrm{Li}, 2011) \\
\text { (Kim et al., 2014) }\end{array}$ \\
\hline
\end{tabular}

Note: All references refer to "autogenous healing" except those market with an asterisk $(*)$ which correspond to "engineered healing"

as recovery of strength, in HPFRC specimens with crystalline admixtures (Ferrara et al., 2016a). The authors claimed that the synergy between the somewhat expansive action of crystalline admixtures and fibers may lead to some kind of chemical prestressing which greatly enhances the natural performance mechanism.

Also recently, Sahmaran (2015) observed that depending on the type of mineral admixture used for self-healing (fly ash or slag) and the duration of the initial curing, ECC specimens can recover up to $85 \%$ of their resonant frequency values, even after six repetitive preloading applications (Sahmaran et al., 2015). Sahmaran et al. (2015) carried out permeability tests and resonant frequency analysis to verify sealing of cracks, while to verify healing of cracks mechanical techniques were applied such as bending and tensile tests (Table 8).

Durability plays a key role in these researches, in this sense, self-healing indices to quantify the recovery of mechanical properties have been defined. It is intended that a "healable crack width", defined as a function of the material composition, the environmental exposure and service conditions, can replace the fixed "allowable crack width" concept as currently formulated in the design codes (Ferrara et al., 2016a).

\section{Self-healing Capability of Fiber Reinforced Cementitious Composites. What Next?}

It has been observed that FRCCs and, of course, HPFRCCs and ECCs, combine the qualities of a high performance concrete with crack width control and energy absorption capacity (Snoeck and De Belie, 2015a). If these qualities are combined with selfhealing the result is very encouraging for the future because it results in a very durable material. Concrete durability is of great concern in the construction field, therefore its improvement is a topic of great interest to researchers.

After a deep analysis on the existing literature published on self-healing capability of fiber reinforced concretes, it is concluded that deeper investigation is needed on the following aspects:

- Healing capacity under sustained stress.

- Effects of self-healing reactions on the fiber matrix-bond.

- Performance based durability concepts to incorporate selfhealing outcomes into durability-based design approach for cement-based materials, mainly for strain-hardening materials as HPFRCCs and ECCs.

- Autogenous healing on corrosion, since it would be very important for the maintenance and durability of structures.

- Use of natural fibers as self-healing facilitators also as a lowcost alternative for steel and synthetic fibers.

- Knowledge on the mechanisms involved in long term performance as tensile creep of HPFRCC.

- The development of standard test methods would be very useful to compare the efficiency of each test self-healing method.

- Durability of ECC in alkaline environments, investigating changes of matrix toughness and fiber/matrix interface properties.

- The nature and the properties of the healing products and the 
reactions which take place depending of the exposure environment performing tests such as Differential Thermo-Gravimetric Analysis and nanocharacterization techniques. In that way, the amount of recovery of the engineering material performance could be correlated with the amount of crack sealing.

- Development of the self-healing method with capsules in order to guarantee the survival of the capsules during the concrete mixing interfering as little as possible in the mechanical properties of the concrete.

\section{Conclusions}

This paper has summarized the research carried out so far on the self-healing capacity of FRCCs (What now?). After a deep analysis on the existing literature on this topic, future perspectives, developments and outlook have been highlighted (What next?).

Therefore, what now?

Repairing structures by means of self-healing increases both the service life and durability of structures. This healing process is affected by some factors such as concrete mix design, water characteristics, crack width and stability.

In turn, the self-healing process can be of two types: autogenous healing or engineered healing. In the first case, healing is obtained through the choice and correct dosage of components used commonly in concrete production. In the case of engineered healing specific substances or additives are activated at the opening of the cracks being added into the concrete to carry out the self-healing phenomenon. Fibers improve self-healing process due to their capacity to control crack widths and enhance multiple crack formation.

And, what next?

It has proven that self-healing of concrete plays a key role on the durability of the structures. For that reason, deeper investigation is needed in some aspects such as healing capacity under sustained stress, effects of self-healing reactions on the fiber matrix-bond and the role of self-healing on corrosion. Outcomes of self-healing on the engineering properties of the material (physical and mechanical) have to be incorporated to a durability based design framework. A "healable crack width", defined as a function of the material composition, the environmental exposure and service conditions, can replace the fixed "allowable crack width" concept as currently formulated in the design codes. On the other hand, the development of standard test methods would be very useful to compare the efficiency of each test self-healing method.

Regarding the future use of self-healing materials in largescale structural applications, two key aspects should be take into account: firstly, the feasability of industrial production of selfhealing materials should be evaluated. Secondly, it is essential to obtain the confidence of contractors and owners of the structures to demonstrate them that self-healing materials are reliable to be used in the construction field.

Finally, to achieve all of these objectives is evident that it is needed a complete cross-disciplinary collaboration between the researchers of all the implied areas on self-healing as chemistry, material science and civil engineering.

\section{Acknowledgements}

The authors acknowledge the financial support of the PoliMi International Fellowships 2015 (PIF), Politecnico di Milano, Milano, Italy.

\section{References}

ACI. Committee.212 (2010). Report ACI 212-3R-10: Report on chemical admixtures for concrete, American Concrete Institute ACI.

Aldea, C., Song, W., Popovics, J., and Shah, S. (2000). "Extend of healing of cracked normal strength concrete." Journal of Materials Civil Engineering, Vol. 12, pp. 92-96, DOI: 10.1061/(ASCE)08991561(2000)12:1(92).

Altmann, F., \& Mechtcherine, V. (2013). Durability design strategies for new cementitious materials. Cement and Concrete Research, 54, 114-125, DOI: 10.1016/j.cemconres.2013.08.008.

Cuenca, E. (2015b). On shear behavior of structural elements made of steel fiber reinforced concrete, Springer, DOI: 10.1007/978-3-31913686-8.

Cuenca, E. and Serna, P. (2010). "Shear behavior of Self-Compacting concrete and Fiber-Reinforced concrete push-off specimens." In D. Feys, Design, production and placement of self-consolidating concrete (pp. 429-438). RILEM Bookseries, DOI: 10.1007/978-90481-9664-7_36.

Cuenca, E. and Serna, P. (2013a). "Failure modes and shear design of prestressed hollow core slabs made of fiber-reinforced concrete." Composites Part B: Engineering, Vol. 45, No. 1, pp. 952-964, DOI: 10.1016/j.compositesb.2012.06.005.

Cuenca, E. and Serna, P. (2013b). "Shear behavior of prestressed precast beams made of self-compacting fiber reinforced concrete." Construction and Building Materials, Vol. 45, pp. 145-156, DOI: 10.1016/ j.conbuildmat.2013.03.096.

Cuenca, E., Echegaray-Oviedo, J., and Serna, P. (2015a). "Influence of concrete matrix and type of fiber on the shear behavior of selfcompacting fiber reinforced concrete beams." Composites Part B: Engineering, Vol. 75, pp. 135-147, DOI: 10.1016/j.compositesb. 2015.01.037.

De Rooij, M., Van Tittelboom, K., De Belie, N., and Schlangen, E. (2013). Self-Healing Phenomena in Cement-Based Materials. Stateof-the-art Report. Springer. RILEM Technical Committee 221-SHC.

Edvarsen, C. (1999). Water Permeability and Autogenous Healing of Cracks in Concrete. ACI Materials Journal, Vol. 96, No. 4, pp. 448454, DOI: $10.14359 / 645$.

Ferrara, L., Albertini, I., Gettu, R., Krelani, V., Moscato, S., Pirritano, F., and Theeda, S. (2015b). "Self-healing of cement based materials engineered through crystalline admixtures: Experimental results form a multinational university network." ACI Special Publication, Vol. 305, No. 13, pp. 1-10.

Ferrara, L., Ferreira, S., Krelani, V., Della Torre, M., Silva, F., and Toledo, R. (2015a). "Natural fibers as promoters of autogenous healing in HPFRCCs: Results from on-going Brazil-Italy cooperation." $A C I$ Special Publication, Vol. 305, No. 11, pp. 1-10.

Ferrara, L., Krelani, V., and Carsana, M. (2014a). "A "fracture testing" based approach to assess crack healing of concrete with and without 
crystalline admixtures." Construction and Building Materials, Vol. 68, pp. 535-551, DOI: 10.1016/j.conbuildmat.2014.07.008.

Ferrara, L., Krelani, V., and Moretti, F. (2016a). "On the use of crystalline admixtures as promoters of self-healing in cement based construction materials." Smart Materials and Structures, Vol. 25, No. 8, DOI: 10.1088/0964-1726/25/8/084002.

Ferrara, L., Krelani, V., and Moretti, F. (2016c). “Autogenous healing on the recovery of mechanical performance of High Performance Fibre Reinforced Cementitious Composites (HPFRCCs): part 2 - correlation between healing of mechanical performance and crack sealing." Cement and Concrete Composites, Vol. 73, pp. 299-315, DOI: 10.1016/j.cemconcomp.2016.08.003.

Ferrara, L., Krelani, V., Moretti, F., Roig-Flores, M., and Serna, P. (2016b). "Effects of autogenous healing on the recovery of mechanical performance of High Performance Fibre Reinforced Cementitious Composites (HPFRCCs): part 1." Cement and Concrete Composites -Submitted-.

Ferrara, L., Rocha Ferreira, S., Krelani, V., Nunes da Cunha Moreira, T., De Andrade Silva, F., and Dias Toledo Filho, R. (2017a). "Selfhealing capacity of hybrid sisal-steel fiber reinforced cementitious composites." Part I: effect of crack healing on the recovery of mechanical performance (Submitted).

Ferrara, L., Rocha Ferreira, S., Krelani, V., Nunes da Cunha Moreira, T., De Andrade Silva, F., and Dias Toledo Filho, R. (2017b). "Selfhealing capacity of hybrid sisal-steel fiber reinforced cementitious composites." Part II: correlation between healing of mechanical performance and crack sealing and comparison with steel-only HPFRCC (Submitted).

Fisher, G. and Li, V. (2002). "Effect of matrix ductility on deformation behavior of steel-reinforced ECC flexural members under reversed cyclic loading conditions." ACI Structural Journal, Vol. 99, No. 6, pp. 781-790, DOI: 10.14359/12343.

Fukuyama, H. and Suwada, H. (2003). "Experimental response of HPFRCC dampers for structural control." Journal of Advanced Concrete Technology, Vol. 1, No. 3, pp. 317-326, DOI: 10.3151/jact.1.317.

Garas, V., Kahn, L., and Kurtis, K. (2009). "Short-term tensile creep and shrinkage of ultra-high performance concrete." Cement and Concrete Composites, Vol. 31, pp. 147-152, DOI: 10.1016/j.cemconcomp. 2009.01.002.

Hearn, N. and Morley, C. (1997). "Self-sealing property of concrete Experimental evidence." Materials and Structures, Vol. 30, No. 201, pp. 404-411.

Homma, D., Mihashi, H., and Nishiwaki, T. (2009). "Self-healing capability of fibre reinforced cementitious composites." Journal of Advanced Concrete Tecnology, Vol. 7, No. 2, pp. 217-228, DOI: 10.3151/ jact.7.217.

Jacobsen, S. and Sellevold, E. (1995). "Self-healing of high strength concrete after deterioration by freeze/thaw." Cement and Concrete Research, Vol. 26, pp. 55-62, DOI: 10.1016/0008-8846(95)00179-4.

Kan, L., Shi, H., Sakulich, A., and Li, V. (2010). "Self-healing characterization of engineered cementitious composite materials." $A C I$ Materials Journal, Vol. 107, No. 6, pp. 617-624, DOI: 10.14359/ 51664049.

Kim, D., Kang, S., and Ahn, T. (2014). "Mechanical characterization of high-performance steel-fiber reinforced cement composites with self-healing effect." Materials, Vol. 7, No. 1, pp. 508-526, DOI: 10.3390/ma7010508.

Kim, J. and Schlangen, E. (2011). "Self-healing in ECC stimulated by SAP under flexural cyclic load." 3rd International Conference on Self-Healing Materials. Bath.
Li, M. and Li, V. (2011). "Cracking and healing of Engineered Cementitious Composites under chloride environment." ACI Materials Journal, Vol. 108, No. 3, pp. 333-340, DOI: 10.14359/51682499.

Li, V. (1992a). "Postcrack scaling relations for fiber reinforced cementitious composites." Journal of Materials in Civil Engineering, Vol. 4, No. 1, pp. 41-57, DOI: 10.1061/(ASCE)0899-1561(1992)4:1(41).

$\mathrm{Li}, \mathrm{V}$. C. (2012). "Tailoring ECC for special attributes: A review." International Journal of Concrete Structures and Materials, Vol. 6, No. 3, pp. 135-144, DOI: 10.1007/s40069-012-0018-8.

Li, V. and Leung, C. (1992b). "Steady-state and multiple cracking of short random fiber reinforced brittle matrix composites." Journal of Engineered Mechanics, Vol. 118, No. 11, pp. 2246-2264, DOI: 10.1061/(ASCE)0733-9399(1992)118:11(2246).

Li, V., Lim, Y., and Chan, Y. (1998). "Feasibility of a passive smart selfhealing cementitious composite." Composites Part B: Engineering, Vol. 29, pp. 819-827, DOI: 10.1016/S1359-8368(98)00034-1.

Li, V., Wang, S., and Wu, C. (1997). "Tensile strain-hardening behavior of polyvinyl alcohol engineered cementitious composites (PVAECC)." ACI Materials Journal, Vol. 98, pp. 483-492, DOI: 10.14359/ 10851.

Lv, Z. and Chen, D. (2014). "Overview of recent work on self-healing in cementitious materials." Materiales de Construcción, Vol. 64, No. 316, pp. 1-12, DOI: 10.3989/mc.2014.05313.

Martinelli, E., Barros, J., Etse, G., Ferrara, L., Folino, P., Koenders, E., and Toledo-Filho, R. (2015). "The Encore Project: Sustainable solutions for cementitious materials." ACI Special Publication, Vol. 305, No. 41, pp. 1-10.

Mihashi, H. and De Leite, J. (2004). "State of the art report on control of cracking in early age concrete." J. Adv. Concrete and Technology, Vol. 2, No. 2, pp. 141-154, DOI:10.3151/jact.2.141.

Mihashi, H. and Nishiwaski, T. (2012). "Development of Engineered Self-healing and Self-repairing concrete." Journal of Advanced Concrete Technology, Vol. 10, pp. 170-184, DOI: 10.3151/jact.10.170.

Nishiwaki, T., Koda, M., Yamada, M., Mihashi, H., and Kikuta, T. (2012). "Experimental study on self-healing capability of FRCC using different types of synthetic fibers." Journal of Advanced Concrete Technology, Vol. 10, pp. 195-206, DOI: 10.3151/jact.10.195.

Nishiwaki, T., Kwon, S., Homma, D., Yamada, M., and Mihashi, H. (2014). "Self-healing capability of fiber-reinforced cementitious composites for recovery of watertightness and mechanical properties." Materials, Vol. 7, pp. 2141-2154, DOI: 10.3390/ma7032141.

Nishiwaki, T., Mihashi, H., Jang, B., and Miura, K. (2006). Development of "Self-Healing system for concrete with selective heating around crack." Journal of Advanced Concrete Technology, Vol. 4, No. 2, pp. 267-275, DOI: 10.3151/jact.4.267.

Nishiwaki, T., Sasaki, H., Kwon, S., Igarashi, G., and Mihashi, H. (2015). Experimental study on self-healing effect of FRCC with PVA fibers and additives against freeze/thaw cycles, Proceedings of ICSHM 2015.

Ohama, Y., Demura, K., and Endo, T. (1992). "Strength properties of epoxy-modified mortars without hardener." Proceedings of the 9th International Congress on the Chemistry of Cement, (pp. 512-516). New Delhi, India.

Özbay, E., Sahmaran, M., Yücel, H., Erdem, T., Lachemi, M., and Li, V. (2013). "Effect of sustained flexural loading on self-healing of engineered cementitious composites." Journal of Advanced Concrete Technology, Vol. 11, pp. 167-179, DOI: 10.3151/jact.11.167.

Qian, S., Zhou, J., and Schlangen, E. (2010). "Influence of curing condition and precracking time on the self-healing behavior of Engineered Cementitious Composites." Cement and Concrete Composites, Vol. 
32, No. 9, pp. 686-693, DOI: 10.1016/j.cemconcomp.2010.07.015.

Qian, S., Zhou, J., De Rooij, M., Schlangen, E., Ye, G, and Van Breugen, K. (2009). Self-healing behavior of strain hardening cementitious composites incorporating local waste materials. Cement and Concrete Composites, Vol. 31, pp. 613-621, DOI: 10.1016/j.cemconcomp. 2009.03.003.

Reinhardt, H. and Jooss, M. (2003). Permeability and self-healing of cracked concrete as a function of temperature and crack width. Cement and Concrete Research, Vol. 33, pp. 981-985, DOI: 10.1016/S00088846(02)01099-2.

Roig-Flores, M., Moscato, S., Serna, P., and Ferrara, L. (2015). Selfhealing capability of concrete with crystalline admixtures in different environments. Construction and Building Materials, Vol. 86, pp. 111, DOI: 10.1016/j.conbuildmat.2015.03.091.

Rossi, P., Charron, J., Bastien-Masse, M., Tailhan, J., Le Maou, F., and Ramanich, S. (2014). "Tensile basic creep versus compressive basic creep at early ages: Comparison between normal strength concrete and a very high strength fibre reinforced concrete." Materials and Structures, Vol. 47, pp. 1773-1785, DOI: 10.1617/s11527-013-0150-1.

Sahmaran, M. and Li, V. (2008). "Durability of mechanically loaded engineered cementitious composites under highly alkaline environments." Cement and Concrete Composites, Vol. 30, pp. 7281, DOI: 10.1016/j.cemconcomp.2007.09.004.

Sahmaran, M., Yildirim, G., Noori, R., Ozbay, E., and Lachemi, M. (2015). "Repeatability and pervasiveness of Self-Healing in Engineered Cementitious Composites." ACI Materials Journal, Vol. 112, No. 4, pp. 513-522, DOI: 10.14359/51687308.

Sanjuán, M., Andrade, C., and Bentur, A. (1997). "Effect of crack control in mortars containing polypropylene fibers on the corrosion of steel in a cementitious matrix." ACI Materials Journal, Vol. 94, No. 2, pp. 134-141, DOI: 10.14359/294.

Schlangen, E. and De Rooij, M. (2013a). Self-healing phenomena in cement-based materials - TC221-SHC. Retrieved from http://www. rilem.org/gene/main.php?base $=8750 \& g p$ id $=228$.

Schlangen, E. and Sangadji, S. (2013b). "Addressing infrastructure durability and sustainability by self healing mechanisms - recent advances in self healing concrete and asphalt." Procedia Engineering, Vol. 54, pp. 39-57, DOI: 10.1016/j.proeng.2013.03.005.

Schlangen, E., Jonkers, H., Qian, S., and Garcia, A. (2010). "Recent advances on self healing of concrete.: In B. Oh, Fracture Mechanics of Concrete and Concrete Structures - Recent Advances in Fracture Mechanics of Concrete. Proceedings of FraMCoS-7 (pp. 291-298). Seoul: Korea Concrete Institute.

Snoeck, D. (2015c). Self-healing and microstructure of cementitious materials with microfibres and superabsorbent polymers, Ghent University: Doctor in Civil Engineering: Construction Design.

Snoeck, D. and De Belie, N. (2012). "Mechanical and self-healing properties of cementitious composites reinforced with flax and cottonised flax, and compared with polyvinyl alcohol fibres." Biosystems Engineering, Vol. 111, No. 4, pp. 325-335, DOI: 10.1016/j.biosystemseng.2011.12.005.

Snoeck, D. and De Belie, N. (2015a). "From straw in bricks to modern use of microfibers in cementitious composites for improved autogenous healing - A review." Construction and Building Materials, Vol. 95, pp. 774-787, DOI: 10.1016/j.conbuildmat.2015.07.018.

Snoeck, D. and De Belie, N. (2015d). "Repeated autogenous healing in strain-hardening cementitious composites by using superabsorbent polymers." Journal of Materials in Civil Engineering, Vol. 28, No. 1, pp. 1-11, DOI: 10.1061/(ASCE)MT.1943-5533.

Snoeck, D., Dewanckele, J., Cnudde, V., and De Belie, N. (2016). "Xray computed microtomography to study autogenous healing of cementitious materials promoted by superabsorbent polymers." Cement and Concrete Composites, Vol. 65, pp. 83-93, DOI: 10.1016/j.cemconcomp.2015.10.016.

Snoeck, D., Smetryns, P., and De Belie, N. (2015b). "Improved multiple cracking and autogenous healing in cementitious materials by means of chemically-treated natural fibres." Biosystems Engineering, Vol. 139, pp. 87-99, DOI: 10.1016/j.biosystemseng.2015.08.007.

Snoeck, D., Van Tittelboom, K., Steuperaert, S., Dubruel, P., and De Belie, N. (2014). Self-healing cementitious materials by the combination of microfibers and superabsorbent polymers. Journal of Intelligent Material Systems and Structures, Vol. 25, No. 1, pp. 13-24, DOI: 10.1177/1045389X12438623.

Tang, W., Kardani, O., and Cui, H. (2015). "Robust evaluation of selfhealing efficiency in cementitious materials - A review." Construction and Building Materials, Vol. 81, pp. 233-247, DOI: 10.1016/ j.conbuildmat.2015.02.054.

Van Tittelboom, K. and De Belie, N. (2013b). "Self-healing in Cementitious Materials. A Review." Materials, Vol. 6, pp. 2182-2217, DOI: 10.3390/ma6062182.

Van Tittelboom, K., Gruyaert, E., Rahier, H., and De Belie, N. (2012). "Influence of mix composition on the extent of autogenous crack healing by continued hydration or calcium carbonate formation." Construction and Building Materials, Vol. 37, pp. 349-359, DOI: 10.1016/j.conbuildmat.2012.07.026.

Van Tittelboom, K., Snoeck, D., Wang, J., and De Belie, N. (2013a). "Most recent advances in the field of self-healing cementitious materials." ICSHM 2013: Proceedings of the 4th International Conference on Self-Healing Materials, (pp. 406-413). Ghent, Belgium.

Wu, M., Johannesson, B., and Geiker, M. (2012). "A review: Self-healing in cementitious materials and engineered cementitious composite as a self-healing material." Construction and Building Materials, Vol. 28, pp. 571-583, DOI: 10.1016/j.conbuildmat.2011.08.086.

Xing, F. and Schlangen, E. (2016). Self-healing concrete - Its efficiency and evaluation - TC SHE. Retrieved from http://www.rilem.org/ gene/main.php?base $=8750 \&$ gp id $=345$.

Yang, Y., Lepech, M., Yang, E., and Li, V. (2009). "Autogenous healing of engineered cementitious composties under wet-dry cycles." Cement and Concrete Research, Vol. 39, pp. 382-390, DOI: 10.1016/ j.cemconres.2009.01.013.

Yang, Y., Yang, E., and Li, V. (2011a). "Autogenous healing of engineered cementitious composites at early age." Cement and Concrete Research, Vol. 41, No. 2, pp. 176-183, DOI: 10.1016/j.cemconres.2010.11.002.

Yildirim, G., Alyousif, A., Sahmaran, M., and Lachemi, M. (2015b). "Assessing the self-healing capability of cementitious composites under increasing sustained loading." Advances in Cement Research, Vol. 27, No. 10, pp. 581-592, DOI: 10.1680/adcr.14.00111.

Yildirim, G., Keskin, O., Keskin, S., Sahmaran, M., and Lachemi, M. (2015a). "A review of intrinsic self-healing capability of engineered cementitious composites: Recovery of transport and mechanical properties." Construction and Building Materials, Vol. 101, pp. 1021, DOI: 10.1016/j.conbuildmat.2015.10.018. 